\title{
Lead Immobilization in Artificial Contaminated Soil Using Sulfur-Impregnated Carbonaceous Rice Straw
}

\author{
T. Wajima
}

\begin{abstract}
A novel carbonaceous immobilizing agent for heavy metal contaminated soil was prepared from rice straw using sulfur immersion and pyrolysis, and the lead immobilization in artificial contaminated soils using sulfur-impregnated carbonaceous material was estimated. The rice straws were cut to $1 \mathrm{~cm}$ pieces, and then immersed in 0.1 - 1 $M K_{2} \mathrm{~S}$ solution for $0-24 \mathrm{~h}$ to prepare sulfur-immersed materials. The immersed-materials were heated at $400{ }^{\circ} \mathrm{C}$ for 1 $h$ in nitrogen gas to produce the sulfur-impregnated carbonaceous material by pyrolysis. The abilities of the product to immobilize lead from aqueous solution were examined to obtain the product with high lead immobilization ability. With increasing $\mathrm{K}_{2} \mathrm{~S}$ concentration, the immobilization ability of the product for lead gradually increases and then above $0.5 \mathrm{M} \mathrm{K}_{2} \mathrm{~S}$ those are almost constant, while $\mathbf{1 5}$ min is sufficient for the immersed time to obtain the product with high lead immobilization ability. The product prepared from material immersed in more than $0.5 \mathrm{M} \mathrm{K}_{2} \mathrm{~S}$ solution for less than $15 \mathrm{~min}$ has a maximum immobilization ability for lead ion. The lead immobilization using the sulfur-impregnated product is sustainable due to the formation of leadhillite $\left[\mathrm{Pb}_{4} \mathrm{SO}_{4}\left(\mathrm{CO}_{3}\right)_{2}(\mathrm{OH})_{2}\right]$ and anglesite $\left[\mathrm{PbSO}_{4}\right]$. The product can immobilize lead ion in various artificial lead contaminated soils. By mixing artificial lead contaminated soil with the sulfur-impregnated product, the eluted solution became neutral, and the eluted concentrations of lead ion dropped below the Japanese elution standard for soil.
\end{abstract}

Index Terms-Soil contamination, lead immobilization, sulfur-impregnation, rice straw, pyrolysis.

\section{INTRODUCTION}

Soil contamination with heavy metals is a worldwide problem. Accumulation of heavy metals in soils affect soil ecology, agricultural productivity, quality of agricultural products, water resources, and serious health problems for human and animal [1]. In the United States, for example, approximately $63 \%$ of the sites on the National Priority List (NPL) for the treatment of contaminated soils are contaminated by metals, and lead is the most common metal, found at $15 \%$ of the sites. In Japan, according to a report by the Ministry of Environment, $43 \%$ of the contaminated sites that exceed the environmental quality standards are contaminated by lead compounds. Soil contamination by lead compounds is also prevalent in other developed and developing countries where lead compounds are used extensively in industrial activities without careful

Manuscript received July 9, 2019; revised February 23, 2020. This work was supported in part by the U.S. Department of Commerce under Grant BS123456 (sponsor and financial support acknowledgment goes here).

T. Wajima is with the Development of Urban Environment Systems, Chiba University, Japan (e-mail: wajima@tu.chiba-u.ac.jp). contamination management.

Lead is a ubiquitous heavy metal pollutant in soils due to their use widely. The primary sources of $\mathrm{Pb}$ contamination include industrial activities such as mining, smelting of metals, and the use of $\mathrm{Pb}$-containing products such as paints, lead-acid batteries, bullets, gasoline and pesticides [2]. It can damage human nervous (especially children) and reproductive systems [3]. The high concentration of $\mathrm{Pb}$ in the soil poses risks to human and animal health by the leaching of metals from the soil into water and the consumption of edible plants growth in the contaminated soil. Therefore, proper remediation is necessary to reduce metal availability in soil for protecting human health.

Among available remediation technologies, in situ immobilization of heavy metals using a chemical amendment can be a cost-effective and environmentally sustainable remediation approach for the immobilization of heavy metals by reducing the mobility and availability. This immobilization technique may provide a long-term remediation solution if low solubility minerals and/or stable precipitates are produced in situ [4]. Therefore, the choice of the soil amendments need that the amendments must reduce heavy metals transfers from contaminated soils to the surface water or groundwater and uptake by plants and organism. The most common agents for lead immobilization are phosphate-based compounds [5]-[7]. Although these studies have successfully demonstrated that phosphates effectively immobilize lead in various contaminated soils, there are several concerns about the use of phosphate as agents for lead immobilization. First, from an environmental protection point of view, excessive supplied phosphate can lead to eutrophication in the natural environment. Second, from a resource conservation point of view, phosphate is becoming a precious element, especially in countries such as Japan that import a major portion of their phosphate requirements. For these reasons, research on other types of lead immobilization agents is needed. Up to now, soil amendments, for example, lime [8], calcium carbonate [9], red-mud [10], fly ash [11] and so on, may decrease leachable concentrations of contaminants and thus reduce the detrimental effects of heavy metals on environmental receptors, such as microorganisms, plants, animals, water and humans [12].

In previous studies, sulfur-impregnated adsorbents with high removal abilities for heavy metals were prepared from paper sludge, cedar bark and rice husk using $\mathrm{K}_{2} \mathrm{~S}$ solution [13]-[15]. According to the Pearson theory, the sulfur, as a soft base, should interact with heavy metals such as $\mathrm{Zn}^{2+}$, $\mathrm{Pb}^{2+}, \mathrm{Cd}^{2+}$ and $\mathrm{Ni}^{2+}$ (soft acids) rather than with oxygen (a hard base) in the activated carbon. From these results, it would be possible to produce a low cost agent to immobilize 
the metal ions in contaminated soils from agricultural waste.

From these background, in this study, we attempted to prepare the lead immobilization agent from rice straw, which is produced as a by-product of rice production, using sulfur-impregnation, and lead immobilization ability of the sulfur-impregnated product was estimated using artificial lead contaminated soils.

\section{MATERIALS AND METHODS}

\section{A. Raw Sample}

Raw rice straw, which was collected from a cultivated area in Akita prefecture, Japan, first cut into $1 \mathrm{~cm}$ length, was then washed with distilled water, and dried and stored for use. Properties of rice straw sample are shown in Table I, and mineralogical composition of rice straw is shown in Fig. 1, which indicates that rice straw mainly composed of cellulose. All reagents were purchased from Wako Chemical Co., Japan at analytical grade.

TABLE I: PROPERTIES OF RICE STRAW SAMPLE

\begin{tabular}{lcccccc}
\hline \hline \multirow{2}{*}{ Moisture } & \multirow{2}{*}{ Ash } & \multicolumn{4}{c}{ Volatile matter + Fixed carbon } \\
\cline { 4 - 7 } & & $\mathrm{C}$ & $\mathrm{H}$ & $\mathrm{N}$ & $\mathrm{S}$ \\
\hline Content $(\%)$ & 7.3 & 11.6 & 39.2 & 6.3 & 0.6 & 0.8 \\
\hline \hline
\end{tabular}

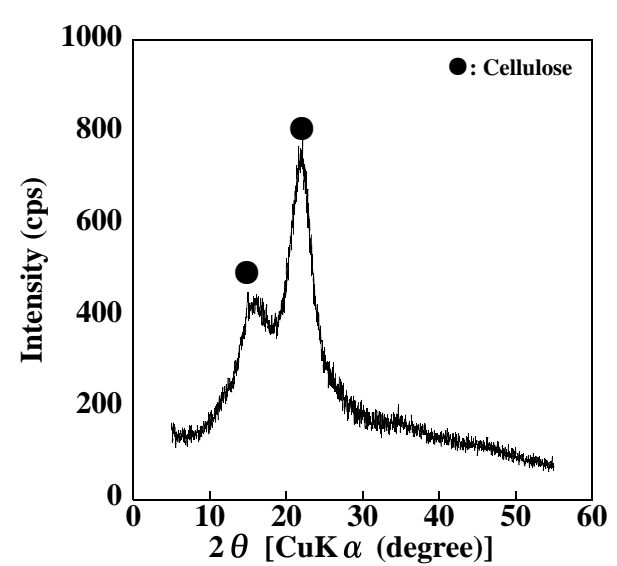

Fig. 1. XRD patterns of rice straw.

\section{B. Sulfur Impregnation}

$20 \mathrm{~g}$ of sample was immersed in $200 \mathrm{~mL}$ of $0.1-1 \mathrm{M} \mathrm{K}_{2} \mathrm{~S}$ solution for $0-24 \mathrm{~h}$, then filtered, and dried in a drying oven overnight to obtain sulfur-immersed samples. These samples were pyrolyzed using a horizontal reactor. Sulfur-immersed samples were put in a ceramic board, and installed in a transparent quartz tube of $0.45 \mathrm{~mm}$ inside diameter and $1 \mathrm{~m}$ in length. Before pyrolysis, $\mathrm{N}_{2}$ gas was injected into the tube for $30 \mathrm{~min}$ at a rate of $1.0 \mathrm{~L} / \mathrm{min}$ to replace the air in the tube. The board was heated in an electric furnace at $400{ }^{\circ} \mathrm{C}$ for $1 \mathrm{~h}$, with a continuous flow of $\mathrm{N}_{2}$ gas at a rate of $1.0 \mathrm{~L} / \mathrm{min}$. After heating, the solid was cooled to room temperature with a steady $\mathrm{N}_{2}$ gas flow $(1.0 \mathrm{~L} / \mathrm{min})$ in the tube, then washed with distilled water and dried in drying oven overnight to obtain the sulfur-impregnated material.

The abilities of the material for immobilization of lead ion from aqueous solution were examined as follows. $0.1 \mathrm{~g}$ of the sample was added to $10 \mathrm{~mL}$ of $\mathrm{Pb}\left(\mathrm{NO}_{3}\right)_{2}$ solution with 10 $\mathrm{mM}$ in $50 \mathrm{~mL}$ centrifuged tube, and was shaken in a reciprocal shaker for $24 \mathrm{~h}$. After shaking, the slurry was centrifuged, and the $\mathrm{pH}$ of the supernatant and the concentration of $\mathrm{Pb}^{2+}$ in the supernatant were measured by pH meter (D-53, Horiba) and atomic absorption spectrophotometer (AAS) (AAnalyst200, PerkinElmer), respectively. The immobilization ratios of $\mathrm{Pb}^{2+}$ were calculated using the following equation:

$$
R=\left(C_{0}-C_{e}\right) / C_{0} \times 100
$$

Here, $R=$ Immobilization ratio of $\mathrm{Pb}^{2+}(\%), C_{0}=$ Initial concentration of $\mathrm{Pb}^{2+}$ in the solution $(\mathrm{mg} / \mathrm{L})$, and $C_{e}=$ Measure concentration of $\mathrm{Pb}^{2+}$ in the solution $(\mathrm{mg} / \mathrm{L})$.

The samples were analyzed by powder X-ray diffraction (XRD) with monochromate $\mathrm{CuK} \alpha$ radiation (Ultima IV, Rigaku) and Fourier transform infrared spectrometry (FT-IR) (Nicolet iS5, Thermo Fisher Scientific). The morphologies of the samples were observed using a scanning electron microscope (SEM) (JSM-6510A, JEOL) equipped with an energy-dispersive X-ray spectrometer (EDS).

\section{Lead Immobilization}

Five soil samples, kaolinite, Akadama soil, Kanuma soil, black soil and river sand, were used to prepare artificially lead-contaminated soils. Lead-contaminated soil was artificially prepared by mixing $30 \mathrm{~g}$ of soil sample and 300 $\mathrm{mL}$ of $1000 \mathrm{mg}-\mathrm{Pb} / \mathrm{L}$ aqueous solution (provided by $\left.\mathrm{Pb}\left(\mathrm{NO}_{3}\right)_{2}\right)$ using a rotary stirrer for $6 \mathrm{~h}$. After mixing, the mixture stands at room temperature for 7 days, and then filtrate. The concentration of $\mathrm{Pb}^{2+}$ in the filtrate was measured by AAS to calculate the content of lead in artificially contaminated soils. The solid was dried in air for 7 days to obtain artificially contaminated soil.

$1 \mathrm{~g}$ of artificially contaminated soil without or with 0.01 $0.1 \mathrm{~g}$ of sulfur-impregnated product was added into $50 \mathrm{~mL}$ of a conical flask, and $10 \mathrm{~mL}$ of distilled water was then poured. The flask was shaken with shaking incubator at $50{ }^{\circ} \mathrm{C}$ for $6 \mathrm{~h}$, and then filtrate. The $\mathrm{pH}$ of the filtrate was measured by $\mathrm{pH}$ meter, and the eluted concentration of $\mathrm{Pb}^{2+}$ in the filtrate is measured by AAS.

\section{RESULTS AND DISCUSSION}

\section{A. Lead Immobilization of Sulfur-Impregnated Product}

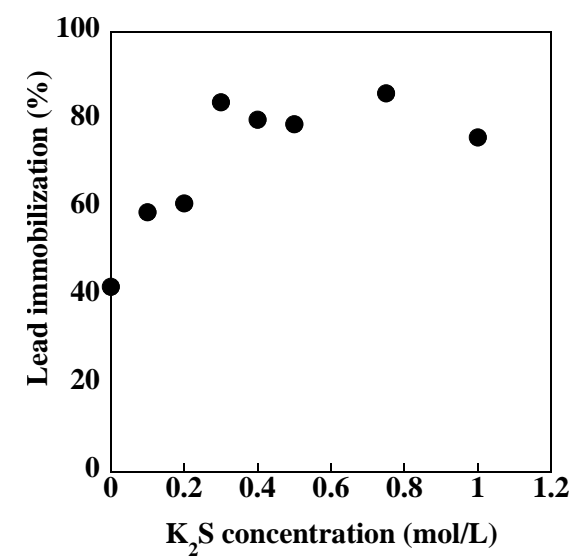

Fig. 2. Lead immobilization of the product from rice straw via pyrolysis of the straw immersed in $\mathrm{K}_{2} \mathrm{~S}$ solution with various concentrations. 


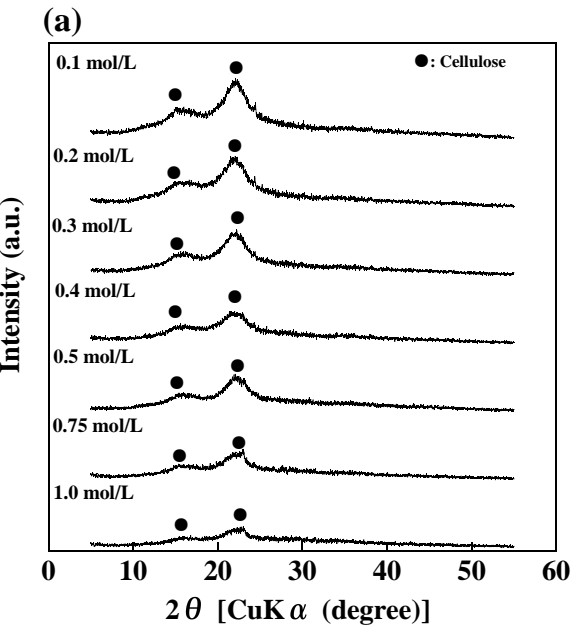

(b)

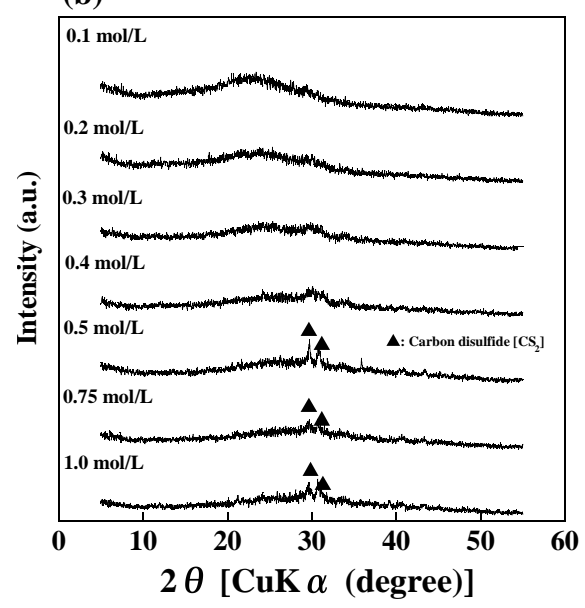

(c)
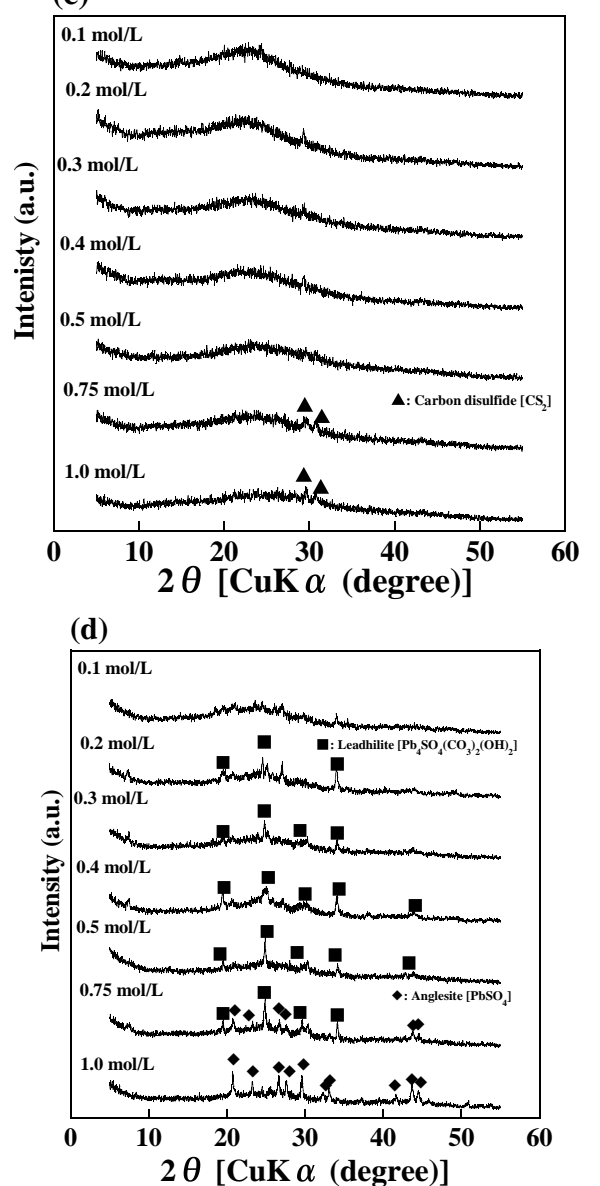

Fig. 3. XRD patterns of (a) immersed straws, (b) pyrolysed immersed straws, (c) the products and (d) the products after lead immobilization test.
Fig. 2 shows the lead immobilization of the product from rice straw via pyrolysis of the straw immersed in $\mathrm{K}_{2} \mathrm{~S}$ solution with various concentrations. With increasing $\mathrm{K}_{2} \mathrm{~S}$ concertation to $0.5 \mathrm{~mol} / \mathrm{L}$, lead immobilization of the product increases, and be almost constant (approximately $80 \%$ ) above $0.5 \mathrm{~mol} / \mathrm{L} \mathrm{K}_{2} \mathrm{~S}$ solution.

Fig. 3 shows the XRD patterns of (a) immersed straws, (b) pyrolysed immersed straws, (c) the products and (d) the products after lead immobilization test. The straws after $\mathrm{K}_{2} \mathrm{~S}$ immersion have cellulose peaks, and the height of the peaks for cellulose decreases with increasing $\mathrm{K}_{2} \mathrm{~S}$ concentration (Fig. 3 (a)). After pyrolysis, the pyrolyzed straws have amorphous structure, and the peaks of carbon disulfide $\left[\mathrm{CS}_{2}\right]$ appears in the pyrolyzed straw immersed in above 0.5 mmol/L K $\mathrm{K}_{2} \mathrm{~S}$ solution (Fig. 3 (b)). The product after washing and drying the pyrolyzed immersed straws also indicates amorphous peak, and the peaks of carbon disulfide remain in the product from the straw immersed in above $0.5 \mathrm{mmol} / \mathrm{L}$ $\mathrm{K}_{2} \mathrm{~S}$ solution (Fig. 3 (c)). After lead immobilization test, leadhilite $\left[\mathrm{Pb}_{4} \mathrm{SO}_{4}\left(\mathrm{CO}_{3}\right)_{2}(\mathrm{OH})_{2}\right]$ and anglesite $\left[\mathrm{PbSO}_{4}\right]$ appear on the product from the straw immersed in $0.1-0.75$ $\mathrm{mol} / \mathrm{L} \mathrm{K}_{2} \mathrm{~S}$ solution and $0.75-1.0 \mathrm{~mol} / \mathrm{L} \mathrm{K}_{2} \mathrm{~S}$ solution, respectively. It would be considered that lead was immobilized by the formation of leadhilite and anglesite due to the reaction of lead ion with sulfur functional on the surface of the product to leadhilite and carbon disulfide to anglesite. In addition, carbon disulfide would precipitate by high concentration of $\mathrm{K}_{2} \mathrm{~S}$ in the solution. From these results, the appropriate product for lead immobilization can be prepared from the straw immersed in $0.5 \mathrm{~mol} / \mathrm{L} \mathrm{K}_{2} \mathrm{~S}$ solution.

Fig. 4 shows the lead immobilization of the product from rice straw via pyrolysis of the straw immersed in $0.5 \mathrm{~mol} / \mathrm{L}$ $\mathrm{K}_{2} \mathrm{~S}$ solution for various times. With increasing immersion time, lead immobilization of the product rapidly increases, and then be almost constant (about $80 \%$ ) after $15 \mathrm{~min}$.

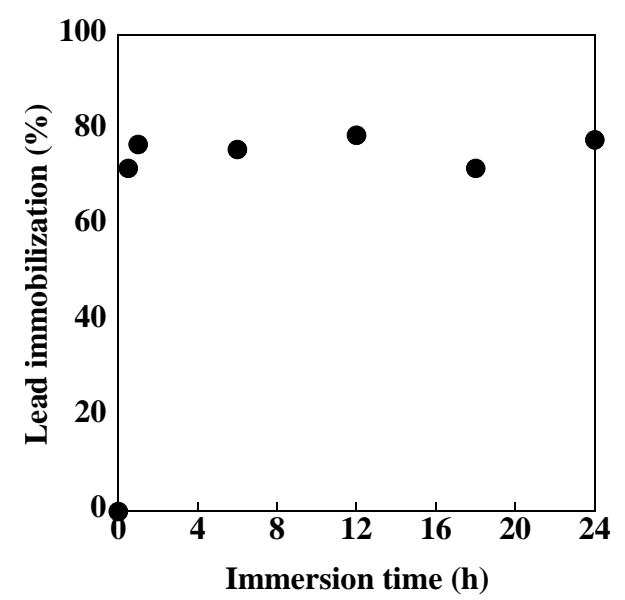

Fig. 4. Lead immobilization of the product from rice straw via pyrolysis of the straw immersed in $0.5 \mathrm{~mol} / \mathrm{L} \mathrm{K}_{2} \mathrm{~S}$ solution for various times.

Fig. 5 shows the XRD patterns of (a) immersed straws, (b) pyrolysed immersed straws, (c) the products and (d) the products after lead immobilization test. The straws after $\mathrm{K}_{2} \mathrm{~S}$ immersion have cellulose peaks (Fig. 5 (a)), the pyrolyzed straws have amorphous structure with the peaks of carbon disulfide (Fig. 5 (b)) and the product indicates amorphous peak without the peaks of carbon disulfide (Fig. 5 (c)). After lead immobilization test, leadhilite $\left[\mathrm{Pb}_{4} \mathrm{SO}_{4}\left(\mathrm{CO}_{3}\right)_{2}(\mathrm{OH})_{2}\right]$ 
appears on the product from the straw immersed in $0.5 \mathrm{~mol} / \mathrm{L}$ $\mathrm{K}_{2} \mathrm{~S}$ solution after 15 min immersion, which means that the appropriate product for lead immobilization can be prepared from the straw immersed in $0.5 \mathrm{~mol} / \mathrm{L} \mathrm{K}_{2} \mathrm{~S}$ solution within 15 min immersion.

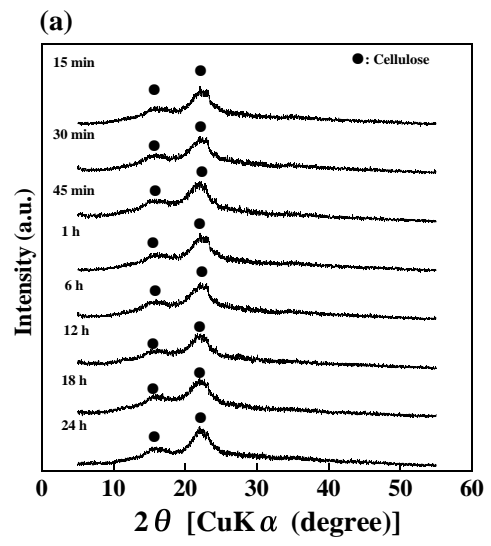

(b)
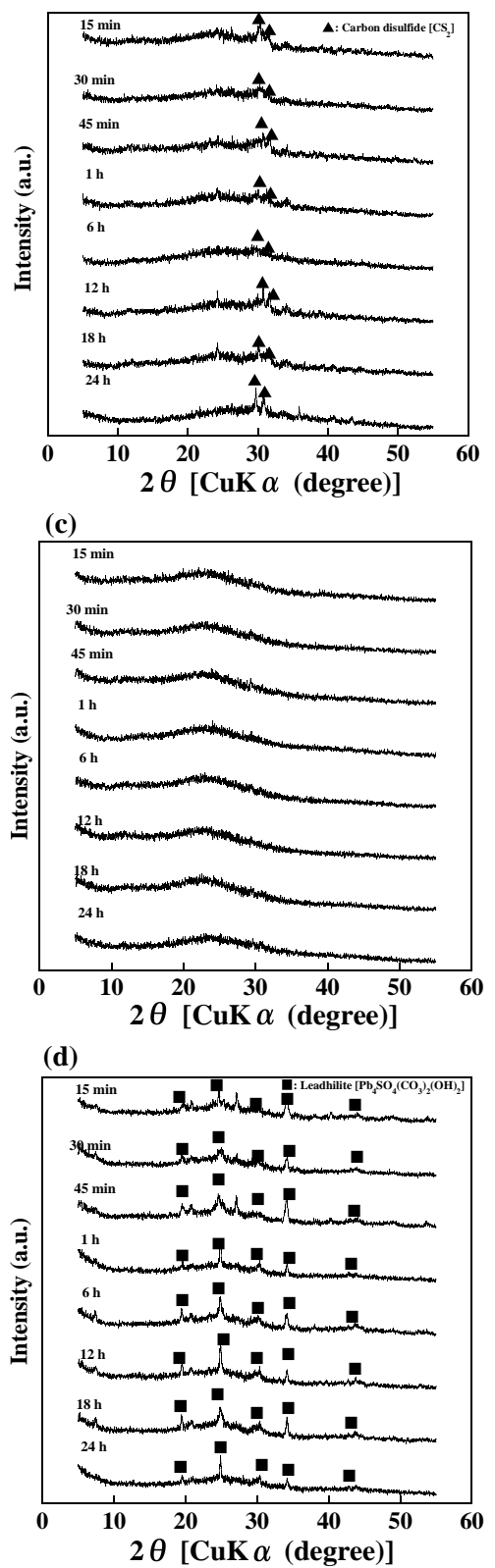

Fig. 5. XRD patterns of (a) immersed straws, (b) pyrolysed immersed straws, (c) the products and (d) the products after lead immobilization test.

From these results, lead immobilization agent can be prepared from rice straw via pyrolysis of the rice straw immersed in $0.5 \mathrm{~mol} / \mathrm{L} \mathrm{K}_{2} \mathrm{~S}$ solution for $15 \mathrm{~min}$.

Fig. 6 shows the photos of (a) rice straw, (b) sulfur-immersed straws, and (c) the products. It is noted that rice straw was immersed in $0.5 \mathrm{~mol} / \mathrm{L} \mathrm{K}_{2} \mathrm{~S}$ solution for 15 min. Rice straw are $1 \mathrm{~cm}$ pieces, and almost same shape after immersion (Fig. 6 (a), (b)). After pyrolysis, the straws are black pieces with shorter than $1 \mathrm{~cm}$ length (Fig. 6 (c)). It is noted that yield of the product is $25-30 \%$ weight of raw rice straw. (a)

(b)

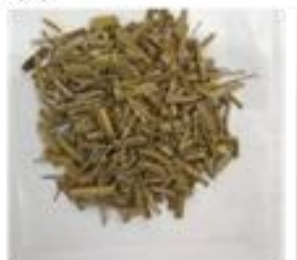

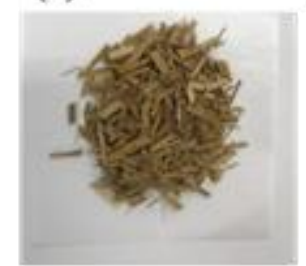

(c)

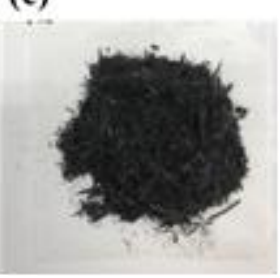
products.
Fig. 7 shows the lead immobilization of rice straw, sulfur-immersed straw and product. Lead immobilization of rice straw and sulfur-immersed straw are $38 \%$ and $42 \%$, respectively, while that of the product is $80 \%$, which means that pyrolysis with sulfur content is important for lead immobilization.

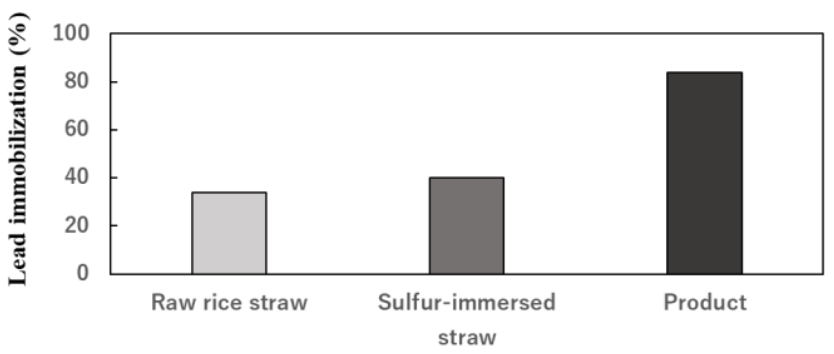

Fig. 7. Lead immobilization of rice straw, sulfur-immersed straws, and the products.

Fig. 8 shows that FT-IR spectra of rice straw, sulfur-immersed straws, and the products. These exhibits absorption bands with $3350-3550 \mathrm{~cm}^{-1}$ due to hydroxyl groups. Rice straw and immersed straw indicate the absorption bands of methyl and methylene groups in the range 2960 - $2850 \mathrm{~cm}^{-1}$, while these bands disappear in pyrolyzed immersed straw and product due to the pyrolysis of organic contents. Aromatic $\mathrm{C}=\mathrm{C}$ group absorbs in the range around $1640 \mathrm{~cm}^{-1}$ and $1360 \mathrm{~cm}^{-1}$, carboxyl $\mathrm{C}=\mathrm{O}$ groups in the range around $1730 \mathrm{~cm}^{-1}$, and these bands become stronger after pyrolysis due to the carbonization. After sulfur-immersion, the absorption band of $710 \mathrm{~cm}^{-1}$ for C-S group and that of $1275-1303 \mathrm{~cm}^{-1}$ for $\mathrm{C}=\mathrm{S}$ group appear. Therefore, carboxyl and sulfur functional group was formed on the surface of product.

Fig. 9 shows the SEM photos of (a) rice straw, (b) sulfur-immersed straws, and (c) the products. It can be observed that rice straw has spherical particles on the surface (Fig. 9 (a)) and these particles are covered with many short needle-like crystals after $\mathrm{K}_{2} \mathrm{~S}$ immersion (Fig. 9 (b)). The product has some pores without spherical particles with needle-like crystals (Fig. 9 (c)). It is noted that the high $\mathrm{Si}$ 
content in raw rice straw, high contents of $\mathrm{K}$ and $\mathrm{S}$ in sulfur-immersed straw, and low Si content were detected by EDS analysis. It would be considered that needle-like $\mathrm{K}_{2} \mathrm{~S}$ crystals cover the silica particles on the surface of rice straw after $\mathrm{K}_{2} \mathrm{~S}$ immersion, and silica particle is reacted with $\mathrm{K}$ to form potassium silicate during the pyrolysis to remove by dissolving on washing process.

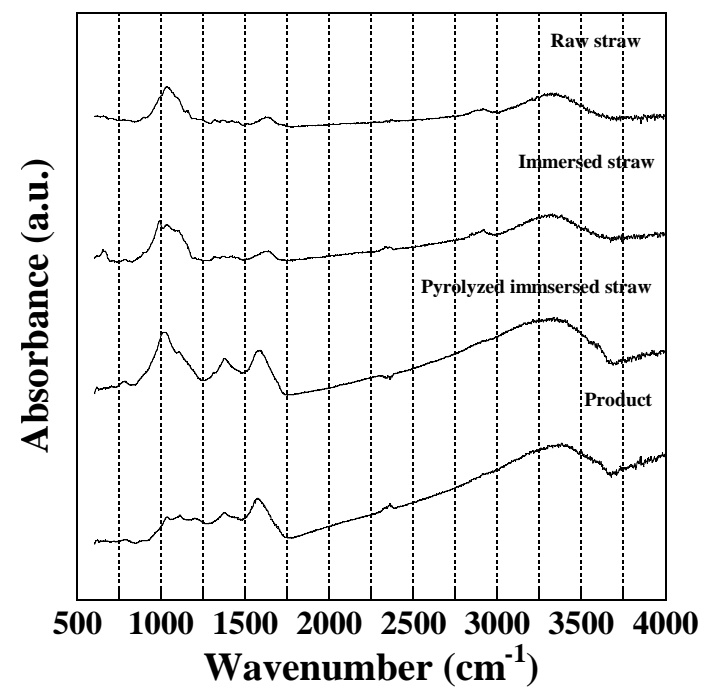

Fig. 8. FT-IR spectra of rice straw, sulfur-immersed straws, and the products.

Therefore, the lead immobilization of the product is caused by porous structure with sulfur functional groups. (a)

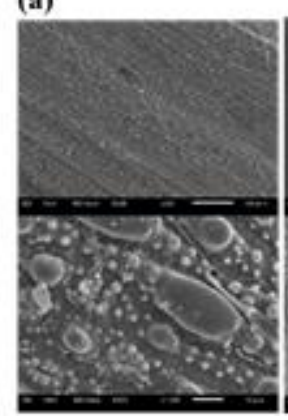

(b)

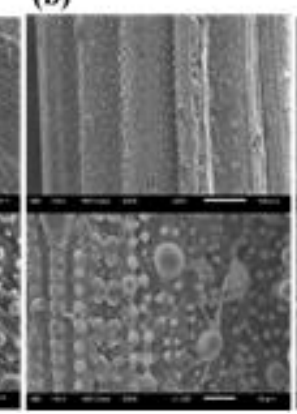

(c)

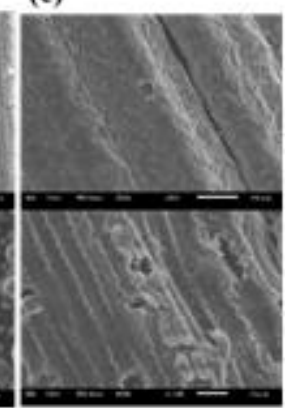

Fig. 9. SEM photos of (a) rice straw, (b) sulfur-immersed straws, and (c) the products.

\section{B. Lead Immobilization}

The lead immobilization of the obtained product was examined using artificial contaminated soils. Table II shows the lead content of artificial contaminated soils used in this experiment. The order of lead content is black soil (9799 $\mathrm{mg} / \mathrm{kg})>$ akadama soil $(8347 \mathrm{mg} / \mathrm{kg})>$ kanuma soil $(6969$ $\mathrm{mg} / \mathrm{kg})>$ river sand $(4185 \mathrm{mg} / \mathrm{kg})>$ kaolinite $(2693 \mathrm{mg} / \mathrm{kg})$.

TABLE II: LEAD CONTENTS OF ARTIFICIAL CONTAMINATED SOIL IN THIS EXPERIMENT

\begin{tabular}{cccccc}
\hline \hline & Kaolinite & $\begin{array}{c}\text { Akadama } \\
\text { soil }\end{array}$ & $\begin{array}{c}\text { Kanuma } \\
\text { soil }\end{array}$ & $\begin{array}{c}\text { Black } \\
\text { soil }\end{array}$ & $\begin{array}{c}\text { River } \\
\text { sand }\end{array}$ \\
\hline $\begin{array}{c}\text { Lead } \\
\text { content } \\
(\mathrm{mg} / \mathrm{kg})\end{array}$ & 2693 & 8347 & 6969 & 9799 & 4185 \\
\hline \hline
\end{tabular}

The effect of sulfur-impregnated product addition on the lead immobilization were determined. Table III shows the $\mathrm{pH}$ of the solution after elution test with addition of sulfur-impregnated product. Without addition of the product, $\mathrm{pH}$ of the solution is weak acidic $(\mathrm{pH} 4-5)$, and with increasing addition of the product, $\mathrm{pH}$ of the solution increased. With addition of $0.1 \mathrm{~g}$ product, $\mathrm{pHs}$ of the solution using akadama soil, kanuma soil and black soil are neutral, while those using kaolinite and river sand are weak alkaline. It would be considered that the product is alkaline material and three soils have $\mathrm{pH}$ buffering ability.

TABLE III: PH OF THE SOLUTION AFTER ELUTION TEST USING ARTIFICIAL CONTAMINATED SOILS

\begin{tabular}{cccccc}
\hline \hline $\begin{array}{c}\text { Addition } \\
(\mathrm{g})\end{array}$ & Kaolinite & $\begin{array}{c}\text { Akadama } \\
\text { soil }\end{array}$ & $\begin{array}{c}\text { Kanuma } \\
\text { soil }\end{array}$ & $\begin{array}{c}\text { Black } \\
\text { soil }\end{array}$ & $\begin{array}{c}\text { River } \\
\text { sand }\end{array}$ \\
\hline 0 & 4.13 & 4.71 & 4.73 & 5.43 & 5.65 \\
0.01 & 5.30 & 5.29 & 5.16 & 5.58 & 6.13 \\
0.05 & 6.82 & 6.38 & 6.17 & 5.86 & 7.06 \\
0.1 & 8.15 & 6.80 & 6.15 & 6.41 & 8.64 \\
\hline \hline
\end{tabular}

Table IV shows the eluted lead concentrations after elution test using artificial contaminated soils. It is noted that Japanese standard of soil elution is less than $0.01 \mathrm{mg} / \mathrm{L}$. Without addition of the product, high concentrations of lead were eluted from kanuma soil $(85.5 \mathrm{mg} / \mathrm{L})$, akadama soil $(63.5 \mathrm{mg} / \mathrm{L})$ and kaolinite $(26.7 \mathrm{mg} / \mathrm{L})$, while elution from black soil $(1.0 \mathrm{mg} / \mathrm{L})$ and river sand $(1.1 \mathrm{mg} / \mathrm{L})$ are low. With increasing addition of the product, the lead elution decreases, and with addition of $0.1 \mathrm{~g}$ product, the lead elution from all samples are not detected using AAS. It would be considered that the product can immobilized lead ion in various soils.

TABLE IV: ELUTED LEAD CONCENTRATION AFTER ELUTION TEST USING ARTIFICIAL CONTAMINATED SOILS

\begin{tabular}{cccccc}
\hline \hline \multirow{2}{*}{$\begin{array}{c}\text { Addition } \\
(\mathrm{g})\end{array}$} & \multirow{4}{*}{ Kead concentration $(\mathrm{mg} / \mathrm{L})$} \\
\cline { 2 - 6 } & & Akadama & Kanuma & Black & River \\
& & soil & soil & soil & sand \\
\hline 0 & 26.7 & 63.5 & 85.5 & 1.0 & 1.1 \\
0.01 & 0.5 & 11.7 & 14.4 & 0.9 & 1.0 \\
0.05 & 0.3 & 0.6 & 0.7 & 0.2 & 1.0 \\
0.1 & N.D. & N.D. & N.D. & N.D. & N.D. \\
\hline \hline
\end{tabular}

From these results, it would be possible that, by mixing lead contaminated soil with sulfur-impregnated product, the eluted solution becomes neutral and the concentration of lead drops below the Japanese eluted standard for soil.

\section{CONCLUSIONS}

A novel carbonaceous immobilizing agent for heavy metal contaminated soil can be prepared from rice straw using sulfur immersion and pyrolysis, and can immobilize lead ion in various artificial lead contaminated soils. The product prepared from material immersed in more than $0.5 \mathrm{M} \mathrm{K}_{2} \mathrm{~S}$ solution for less than 15 min has a maximum immobilization ability for lead ion, and the lead immobilization using the sulfur-impregnated product is sustainable due to the formation of leadhillite and anglesite. With addition of the product, the lead elution from all artificial contaminated soil is lower than Japanese standard of soil elution. In future, long term stability of lead immobilization will be examined to use for field verification test. 


\section{CONFLICT OF INTEREST}

The authors declare no conflict of interest.

\section{AUTHOR CONTRIBUTIONS}

Please state each author's contribution to this work, it can be up to several sentences long and should briefly describe the tasks of individual authors. e.g., T. Wajima conducted the research, analyzed the data, and wrote the paper. Author had approved the final version.

\section{ACKNOWLEDGMENT}

This work was supported by JSPS KAKENHI Grant Number 16K00609.

\section{REFERENCES}

[1] S. Raicevic, T. Kaludjerovic-Radoicic, and A. I. Zouboulis, "In situ stabilization of toxic metals in polluted soils using phosphates: theoretical prediction and experiment verification," J. Hazard. Mater. vol. B117, pp. 41-53, 2005.

[2] X. D. Cao, A. Wahbi, L. N. Ma, B. Li, and Y. L. Yang, "Immobilization of $\mathrm{Zn}, \mathrm{Cu}$, and $\mathrm{Pb}$ in contaminated soils using phosphate rock and phosphoric acid," J. Hazard. Mater., vol. 164, pp. 555-564, 2009.

[3] Agency for Toxic Substances and Disease Registry (ATSDR), Toxicological Profile for Lead, Atlanta, 2007.

[4] J. Vangronsveld and S. D. Cunningham, Introduction to the Concepts. In Metal Contaminated Soils: In Situ Inactivation and Phytorestoration, New York: Springer, 1998. pp. 1-15.

[5] Y. S. Cui, X. Du, L. P. Weng, and W. H. Riemsdijk, "Assessment of in situ immobilization of lead $(\mathrm{Pb})$ and arsenic (As) in contaminated soils with phosphate and iron: Solubility and bioaccessibility," Water Air Soil Pollut., vol. 213, pp. 1-4, 2010.

[6] N. Munksgaard, B. G. Lottermoser, and K. Blake, "Prolonged testing of metal mobility in mining-impacted soils amended with phosphate fertilisers," Water Air Soil Pollut., vol. 223, pp. 2237-2255, 2011.

[7] S. Mignardi, A. Corami, and V. Ferrini, "Evaluation of the effectiveness of phosphate treatment for the remediation of mine waste soils contaminated with $\mathrm{Cd}, \mathrm{Cu}, \mathrm{Pb}$, and $\mathrm{Zn}$," Chemosphere, vol. 86, pp. 354-360, 2012

[8] C. W. Gray, S. J. Dunham, P. G. Dennis, F. J. Zhao, and S. P. McGrath, "Field evaluation of in situ remediation of a heavy metal contaminated soil using lime and red-mud," J. Environ. Pollut., vol. 142, pp. 530-539, 2006.

[9] Y. M. Wang, T. C. Chen, K. J. Yeh, and M. F. Shue, "Stabilization of an elevated heavy metal contaminated site," J. Hazard. Mater., vol. 88, pp. 63-74, 2001.

[10] S. H. Lee, J. S. Lee, Y. J. Choi, and J. G. Kim, "In situ stabilization of cadmium-, lead-, and zinc-contaminated soil using various amendments," Chemosphere, vol. 77, pp. 1069-1075, 2009.

[11] H. David, P. Jonathan, and S. Philippe, "Heavy metal immobilization by cost-effective amendments in a contaminated soil: Effects on metal leaching and phytoavailability," J. Geochem. Explor., vol. 123, pp. 87-94, 2012.

[12] E. Lombi, F. J. Zhao, G. Zhang, B. Sun, W. Fitz, H. Zhang, and S. P. McGrath, "In situ fixation of metals in soils using bauxite residue: chemical assessment," J. Environ. Pollut., vol. 118, pp. 435-443, 2002.

[13] T. Wajima, "Preparation of carbonaceous heavy metal adsorbent from cedar bark using sulfur-impregnation," Int. J. Chem. Eng. Appl., vol. 18, pp. 272-276, 2017.

[14] T. Wajima, "A new carbonacious adsorbent for heavy metal removal from aqueous solution prepared from paper sludge by sulfur-impregnation and pyrolysis," Process Saf. Environ. Prot., vol. 112, pp. 342-352, 2017.

[15] T. Wajima, "Preparation of sulfur-impregnated carbonacious adsorbent from rice husk for heavy metal removal from aqueous solution," Int. J. Environ. Sci. Dev., vol. 9, pp. 38-42, 2018.

Copyright $\odot 2020$ by the authors. This is an open access article distributed under the Creative Commons Attribution License which permits unrestricted use, distribution, and reproduction in any medium, provided the original work is properly cited (CC BY 4.0).

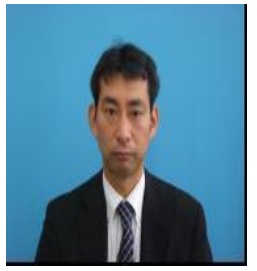

T. Wajima was born in February 1976 in Saga Prefecture, Japan. He has been an associate professor in the Department of Urban Environment Systems, Graduate School of Engineering, Chiba University, Japan, since 2013. He received his bachelor's degree and master's degree in resource engineering from Kyoto University, Japan, in 1998 and 2000, respectively, and his $\mathrm{PhD}$ in environmental mineralogy and technology from Kyoto University, Japan, in 2004. His main $\mathrm{PhD}$ research theme was "micro-porous materials synthesized from paper sludge ash at low temperature, and its chemical mineralogy." In 2004, he moved to the Institute of Ocean Energy at Saga University to work as a postdoctoral researcher, and from 2007 to 2013, he was an Assistant Professor at Akita University, Japan. His main research interests are waste recycling, resource recovery, and environmental purification. 